S. Afr. J. Agric. Ext.

Vol. 47 No. 4, 2019: 86 - 95

http://dx.doi.org/10.17159/2413-3221/2019/v47n4a528
Olorunfemi, Olorunfemi, Adebayo, Letsoalo \& Modirwa

(License: CC BY 4.0)

\title{
COMPETENCY NEEDS OF EXTENSION AGENTS ON VALUE ADDED FISH PRODUCTION: EVIDENCE FROM KWARA STATE, NIGERIA
}

\author{
Olorunfemi, T. O. ${ }^{1}$, Olorunfemi, O. D. ${ }^{2}$, Adebayo, S. A. ${ }^{3}$, Letsoalo, S. S. ${ }^{4}$ and Modirwa, S. ${ }^{5}$
}

Correspondence author: T. O. Olorunfemi. Email: oladeletemitope22@yahoo.com

\section{ABSTRACT}

The need to develop the technical expertise and skills of extension agents on value added fish production in order to ensure that they are properly equipped to meet the changing needs of their clientele led to this study. The paper analysed the competency needs of extension agents on value added fish production in Kwara State, Nigeria. A structured questionnaire was used to elicit information from the total population (total population sampling) of extension agents in Kwara State Agricultural Development Programme (KWADP) due to the relatively small number of extension agents in the organisation. The results showed that the extension agents had a mean age of 40.3 years. The majority of the respondents (72.3\%) were male, married $(88.2 \%)$, with an average household size of five persons. Most of the extension agents $(75.6 \%)$ had ordinary National Diploma certificates and above in their level of education with an average of eight years' experience in the extension profession. Competency upgrade (training) was needed in 10 areas of value added fish production skills and knowledge and the respondents highlighted seven severe constraints militating against their acquisition of needed competencies in value added fish production. Chi-square analysis revealed that respondents' areas of competency needs in value added fish production were influenced by their age, gender, level of education, and years of experience. The study acknowledges that there is a need for the KWADP to develop robust training programmes for extension agents on value added fish production skills in order to enhance their competence in rendering information and advisory services to farmers for a more profitable regime for fish farmers in the study area.

Keywords: Competency needs, Extension agents, Fish production, Value addition,

\section{INTRODUCTION}

According to the Food and Agricultural Organisation (FAO) of the United Nations (FAO, 2018), the fishery sector is an important source of livelihoods to a lot of households which makes a vital contribution to food and nutrition security globally. Fish remains an important source of nutritious and affordable food for the majority of low income households worldwide (Béné et al, 2015). Fish accounts for about 17\% of animal protein consumed globally and about $88.42 \%$ of the total 171 million tonnes of fish produced was consumed by man (FAO, 2018). In Africa, the value added by the fisheries sector in 2011 was estimated at more than US\$ 24 billion, 1.26\% of the Gross Domestic Product (GDP). Among the various fisheries, the highest

\footnotetext{
${ }^{1}$ Agricultural Researcher, North West University (Mafikeng Campus), Mmabatho, Mafikeng, South Africa, Email: oladeletemitope22@yahoo.com, ORCID no: 0000-0001-9749-0904

${ }^{2}$ Lecturer/ Researcher, University of Ilorin, Ilorin, Kwara State, Nigeria, Email: davidsoa2003@yahoo.com

${ }^{3}$ Lecturer/ Researcher, University of Ilorin, Ilorin, Kwara State, Nigeria, Email: sijuadeadebayo@ yahoo.com

${ }^{4}$ Head of Department / Lecturer, North West University (Mafikeng Campus), Mmabatho, Mafikeng, South

Africa, Email: simon.letsoalo@nwu.ac.za

${ }^{5}$ Lecturer, North West University (Mafikeng Campus), Mmabatho, Mafikeng, South Africa, Email:

sinah.modirwa@nwu.ac.za
} 
S. Afr. J. Agric. Ext.

Vol. 47 No. 4, 2019: 86 - 95

http://dx.doi.org/10.17159/2413-3221/2019/v47n4a528
Olorunfemi, Olorunfemi, Adebayo, Letsoalo \& Modirwa

(License: CC BY 4.0)

value is produced by the marine artisanal fisheries $(0.43 \%)$, followed by marine industrial fisheries $(0.36 \%)$, inland fisheries $(0.33 \%)$, and aquaculture $(0.15 \%)$, and was estimated that in the continent, the fisheries and aquaculture sector employs about 12.3 million people (FAO, 2014).

The fishing subsector is also important to the Nigerian economy as it contributed about $0.43 \%$ to the Nigerian GDP in the third quarter of 2017 (National Bureau of Statistics (NBS), 2017). Fish consumption in Nigeria is high as it has the largest market for fish and fishery products in Africa and the consumption per capita is $14.9 \mathrm{~kg}$ per annum (FAO, 2016; Olaoye \& Oloruntoba, 2011). However, despite the large fish market potential available in Nigeria, a lot of fish farmers have not been able to maximise the prospect in the sector due to the underuse of value added fish production techniques (Adefalu et al, 2013; Olorunfemi et al, 2018).

Value added fish production refers to fish farming production methods, initiatives or handling processes utilised to improve all the existing forms of fish processes and products leading to an enhancement in customer base for the product, increase in shelf-life, maintenance of high level of quality, and the accrual of greater proportion of income to farmers (Morrisey, 2011; Olorunfemi et al, 2018; Walia, 2007). Value added fish production has a particular importance in that it offers a strategy for transforming an unprofitable enterprise into a profitable one and because of this potential that it offers, extension agencies and organisations are expected to promote the utilisation of these initiatives amongst fish farmers in Nigeria (Olorunfemi et al, 2017).

The major public extension organisation in Nigeria that renders extension services to farmers is the Agricultural Development Programme (ADP) and the role of the officers in this agency is the effective transfer of innovations and research to farmers, thereby building their capacity as well as their decision making process in solving farm problems, improving agricultural production and enhancing profit maximisation. According to Moore et al (2007), agricultural extension services is an educational programme designed to broaden the scope of extension officials in training the ultimate users of innovation. Therefore, a successful extension service delivery is majorly dependent on the competence of extension agents to transfer initiatives to farmers and this has led to increasing emphasis on the development of the competency necessary for extension personnel to perform their expected role optimally and effectively (Saikia et al, 2013).

According to Olorunfemi et al (2017), most farmers in Nigeria had a low use of value addition initiatives in fishery production due to inadequate knowledge, which can be related to inadequate dissemination of value addition innovation capable of increasing their income and standard of living by the extension agents. According to Brown, Agbulu and Amonjenu (2017), most farmers disembark on fish production due to the inability of the government and other relevant stakeholders to provide the necessary policies and technical facilities for successful and profitable fish production. Furthermore, near absence of effective supporting services such as the intervention of fish extension advisory services in disseminating useful information with regards to fish value added production has led to poor and low quality production. Successful practice of value added fishery production by the farmers requires periodic upgrades of their technical knowledge and skills for better resource utilisation and improved productivity. This means that farmers depend on extension agents to access improved information and technologies, hence extension agents need to be competent in the discharge of their duties, especially on value added fish production (Haleem, 2018; Ifejika, Uzokwe \& Oladosu, 2013). 
S. Afr. J. Agric. Ext.

Vol. 47 No. 4, 2019: 86 - 95

http://dx.doi.org/10.17159/2413-3221/2019/v47n4a528
Olorunfemi, Olorunfemi, Adebayo, Letsoalo \& Modirwa

(License: CC BY 4.0)

In Kwara State, which is used as a case study for this research, poor extension and advisory services have been identified by fish farmers as one of the major severe constraints militating against the use of value added fish production (Olorunfemi et al, 2018). This reveals the inadequacy of fishery extension and advisory services on innovations to these farmers. In light of all these, the low level of use of value added fish production techniques by fish farmers in the study area might be attributed to competency shortfalls from the extension agents who are saddled with the responsibility of ensuring that appropriate and timely innovations get to the farmers and are used by them in order to improve their livelihood. Therefore, there is a need to research the areas of competency deficiencies and needs of extension agents in the study area with regards to value added fish production. This would help to shed light on the areas of capacity building that should be intensified upon by management of extension agencies and other stakeholders so as to fully equip the extension agents in rendering adequate and successful advisory services in fishery. Specifically, the study sought to describe the socioeconomic characteristics of the extension agents in Kwara State, to determine the competency needs of the extension agents on value added fish production, and to identify the constraints to the acquisition of needed competencies on value added fish production by the respondents.

\section{METHODOLODY}

The study was conducted in Kwara State, Nigeria. The state is geographically located between latitude $7^{\circ} 20^{\prime}$ and $11^{\circ} 05^{\prime}$ north of the equator, and longitude $2^{\circ} 05^{\prime}$ and $6^{\circ} 45^{\prime}$ east of the prime meridian (Ogunlade, Oladele \& Babatunde, 2009). It is located in North Central Nigeria and because of this unique geographical location, the state is referred to as the "gateway" between the north and south of the country. The state is divided into three senatorial districts which are Kwara South, Kwara Central and Kwara North, and it has 16 local government areas. Agriculture is the main stay of the economy and $72 \%$ of the population is engaged in this sector. The state provides food crops such as maize, cassava, plantain, banana, cocoyam, onion, fruits, sweet potatoes, vegetables and livestock such as goats, cattle, sheep, fish, pigs, and poultry. In Kwara State, the management of agricultural information (fisheries, crop, livestock or forestry) is saddled on the extension department of the Agricultural Development Programme (ADP) under the aegis of the Federal Ministry of Agricultural and Rural Development. Kwara State is divided into four zones by the Kwara State Agricultural Development Project (KWADP) in consonance with ecological characteristics, cultural practices and project administrative convenience (KWADP, 2015).

The population for this study comprised of the total number of frontline extension agents employed by the KWADP. There are about 120 frontline extension agents in the KWADP, and this total number was used for the study. Data were collected on the socio-economic characteristics of the extension agents, constraints to the acquisition of needed competencies on value added fish production, and the dependent variable was the competency need of the extension agents on value added fish production techniques.

The data obtained was analysed using descriptive statistics such as frequency counts, percentages, means and ranks. The dependent variable of this study was the competency needs of the extension agents on value added fish production. Respondents' areas of competency needs were determined by carrying out a task analysis on their ability to disseminate and teach fish farmers the identified skills on value added fish production using the Difficulty, Importance and Frequency (DIF) Model (Melton \& Bahlis, 2011; Wentling, 1993). The respondents were first asked to state how frequently they disseminate and advise fish farmers 
S. Afr. J. Agric. Ext.

Vol. 47 No. 4, 2019: 86 - 95

http://dx.doi.org/10.17159/2413-3221/2019/v47n4a528
Olorunfemi, Olorunfemi, Adebayo, Letsoalo \& Modirwa

(License: CC BY 4.0)

on these value added fish production skills and their response was rated on a 5-point scale of weekly (5), fortnightly (4), monthly (3), occasionally (2), and not at all (1). The respondents were then asked to rate the importance of these skills to value-added production in fish farming on a 3-point importance scale of very important (3), moderately important (2), and not important (1). Respondents' difficulty in playing their advisory role in teaching and disseminating these value-added production skills were rated on a 4-point scale of extremely difficult (4), very difficult (3), moderately difficult (2), and not difficult (1).

The total mean score for the task analysis of each skill item was computed by adding the mean score for the frequency, importance and difficulty for each item. A mean score of 8 out of a total obtainable score of 12 was adopted as a threshold to determine skill items requiring competency upgrade through training. Those above 8 were noted as skill items where competency upgrade was needed while those below were seen as areas where competency is not currently needed.

Constraints to acquisition of needed competencies on value added fish production: A series of items was presented to the respondents where they were asked to rate these items as constraints on a 5-point Likert-type scale of very severe (5), severe (4), somewhat severe (3), a little severe (2), and not severe (1).

The data collected was analysed using descriptive statistics such as frequency counts, percentages, means and ranks while Chi-square analysis was used to analyse the relationship between the respondents' socio-economic characteristics and their competency needs on value added fish production. This was used to test for the independence between these variables. It helped to determine whether a systematic relationship exists between these variables.

\section{RESULTS AND DISCUSSION}

\subsection{Socio-economic characteristics of the extension agents}

Results from Table 1 show that the mean age of the respondents was 40.3 years, implying that the majority of them are still economically active and still have a high tendency and degree for innovativeness which will enhance their willingness to upgrade their knowledge for more effective performance on the field. This result agrees with that of Idrisa and Ogunbameru (2008) which explained that middle aged persons (normally 25 years to 45 years of age) are found to be most active and appropriate for extension service delivery. In addition, the majority of the respondents $(72.3 \%)$ were male, indicating that KWADP extension service is still predominantly staffed by men. The results further revealed that the majority of the respondents $(88.2 \%)$ were married, with a mean household size of five persons. Furthermore, the majority of the extension agents had an Ordinary National Diploma (OND) certificate and above level of education implying that most of the respondents have basic tertiary education which is expected to contribute to their grasp of value added fish production initiatives for effective onward transfer to farmers. Finally, the mean years of experience was 8.3 years which implies that most of the respondents had experience with regards to extension work. 
Table 1: Socio-economic characteristics of the extension agents

\begin{tabular}{|l|l|}
\hline Socio-economic characteristics & Description \\
\hline Gender & Predominantly Male: $72.3 \%$ \\
\hline Age & Mean $=40.3$ years \\
\hline Marital Status & $88.2 \%$ married \\
\hline Educational qualification & $\begin{array}{l}\text { Predominantly ordinary diploma holders and } \\
\text { above: } 75.6 \%\end{array}$ \\
\hline Household size & Mean $=5$ persons \\
\hline Years of Experience & Mean $=8.3$ years \\
\hline
\end{tabular}

\subsection{Competency need of the extension agents on value added fish production}

The areas of competency upgrade of the extension agents on value added fish production were determined by using the DIF model. The techniques were analysed with the use of total mean score to identify areas where training is needed on value added fish production techniques. Using the mean score bench mark of 8 , the findings from Table 2 show that the prominent areas where competency upgrade on value addition is needed by the extension agents are "Fish seed production and hatchery management" $(\bar{X}=10.87)$, "Addition of additives to enhance taste and output during processing" ( $\bar{X}=10.50)$, "Improved culturing systems (e.g. re-circulatory pond system with sedimentation and bio-towers)" $(\bar{X}=10.36)$, "Brood stock selection" $(\bar{X}=10.24)$, "Post-harvest handling of fishes" $(\bar{X}=10.20)$, and "Knowledge of appropriate product standardization for domestic and export markets" $(\bar{X}=9.96)$. This implies that extension agents in the study area need a competency upgrade in these areas of value added fish production. Therefore, government, extension agencies and other stakeholders in the fish sector should focus more attention on educating and enlightening extension agents, especially on value added fish production skills, by providing training on value added fish production through the appropriate channels.

Table 2: Skill analysis of extension agents on fish farming value added production for determination of competency needs

\begin{tabular}{|c|c|c|c|c|c|}
\hline $\begin{array}{c}\text { Value added fishery } \\
\text { production skills }\end{array}$ & $\begin{array}{c}\text { Frequency of } \\
\text { teaching and } \\
\text { dissemination }\end{array}$ & $\begin{array}{c}\text { Importance } \\
\text { to value } \\
\text { added fish } \\
\text { production }\end{array}$ & $\begin{array}{c}\text { Difficulty of } \\
\text { teaching and } \\
\text { dissemination }\end{array}$ & $\begin{array}{c}\text { Total mean } \\
\text { score }\end{array}$ & Implication \\
\hline $\begin{array}{c}\text { Fish feed formulation } \\
\text { and standard feeding } \\
\text { regimes }\end{array}$ & 3.82 & 2.15 & 3.36 & 9.33 & $\begin{array}{c}\text { Competency } \\
\text { Upgrade } \\
\text { Needed }\end{array}$ \\
\hline $\begin{array}{c}\text { Improved culturing } \\
\text { systems }\end{array}$ & 4.16 & 2.48 & 3.72 & 10.36 & $\begin{array}{c}\text { Competency } \\
\text { Upgrade } \\
\text { Needed }\end{array}$ \\
\hline Pond liming & 3.01 & 2.05 & 2.68 & 7.74 & $\begin{array}{c}\text { Competency } \\
\text { Upgrade Not } \\
\text { Needed }\end{array}$ \\
\hline $\begin{array}{c}\text { Stocking rate of } \\
\text { fingerlings }\end{array}$ & 3.12 & 2.10 & 2.37 & 7.59 & $\begin{array}{c}\text { Competency } \\
\text { Upgrade Not } \\
\text { Needed }\end{array}$ \\
\hline
\end{tabular}


S. Afr. J. Agric. Ext.

Vol. 47 No. 4, 2019: 86 - 95

http://dx.doi.org/10.17159/2413-3221/2019/v47n4a528
Olorunfemi, Olorunfemi, Adebayo, Letsoalo \& Modirwa (License: CC BY 4.0)

\begin{tabular}{|c|c|c|c|c|c|}
\hline $\begin{array}{l}\text { Water management \& } \\
\text { monitoring procedure }\end{array}$ & 3.03 & 1.82 & 2.99 & 7.84 & $\begin{array}{l}\text { Competency } \\
\text { Upgrade Not } \\
\text { Needed }\end{array}$ \\
\hline $\begin{array}{c}\text { Fish seed production } \\
\text { and hatchery } \\
\text { management }\end{array}$ & 4.32 & 2.75 & 3.80 & 10.87 & $\begin{array}{l}\text { Competency } \\
\text { Upgrade } \\
\text { Needed }\end{array}$ \\
\hline $\begin{array}{l}\text { Use of aerators to } \\
\text { oxygenate pond water }\end{array}$ & 2.95 & 1.32 & 2.88 & 7.15 & $\begin{array}{c}\text { Competency } \\
\text { Upgrade Not } \\
\text { Needed }\end{array}$ \\
\hline $\begin{array}{l}\text { Grading and sorting of } \\
\text { fishes }\end{array}$ & 2.07 & 1.72 & 2.22 & 6.01 & $\begin{array}{l}\text { Competency } \\
\text { Upgrade Not } \\
\text { Needed }\end{array}$ \\
\hline Brood stock selection & 4.24 & 2.77 & 3.23 & 10.24 & $\begin{array}{l}\text { Competency } \\
\text { Upgrade } \\
\text { Needed } \\
\end{array}$ \\
\hline $\begin{array}{l}\text { Various fish products } \\
\text { \& by-products }\end{array}$ & 2.00 & 1.24 & 2.73 & 5.97 & $\begin{array}{l}\text { Competency } \\
\text { Upgrade Not } \\
\text { Needed }\end{array}$ \\
\hline $\begin{array}{c}\text { Post-harvest handling } \\
\text { of fishes }\end{array}$ & 3.97 & 2.68 & 3.55 & 10.20 & $\begin{array}{l}\text { Competency } \\
\text { Upgrade } \\
\text { Needed }\end{array}$ \\
\hline $\begin{array}{l}\text { Proper fish degutting - } \\
\text { Evisceration }\end{array}$ & 2.07 & 1.97 & 2.63 & 6.67 & $\begin{array}{l}\text { Competency } \\
\text { Upgrade Not } \\
\text { Needed }\end{array}$ \\
\hline $\begin{array}{l}\text { Addition of additives } \\
\text { to enhance taste \& } \\
\text { output during } \\
\text { processing }\end{array}$ & 4.48 & 2.25 & 3.77 & 10.50 & $\begin{array}{l}\text { Competency } \\
\text { Upgrade } \\
\text { Needed }\end{array}$ \\
\hline Brining & 2.54 & 1.59 & 2.33 & 6.46 & $\begin{array}{l}\text { Competency } \\
\text { Upgrade Not } \\
\text { Needed }\end{array}$ \\
\hline Smoking & 2.30 & 2.41 & 1.54 & 6.25 & $\begin{array}{l}\text { Competency } \\
\text { Upgrade Not } \\
\text { Needed }\end{array}$ \\
\hline Filleting & 2.09 & 2.03 & 2.16 & 6.28 & $\begin{array}{l}\text { Competency } \\
\text { Upgrade Not } \\
\text { Needed }\end{array}$ \\
\hline Barbeque & 3.15 & 1.32 & 2.53 & 7.00 & $\begin{array}{l}\text { Competency } \\
\text { Upgrade Not } \\
\text { Needed } \\
\end{array}$ \\
\hline Pickling & 2.74 & 1.77 & 2.55 & 7.06 & $\begin{array}{l}\text { Competency } \\
\text { Upgrade Not } \\
\text { Needed }\end{array}$ \\
\hline Canning & 2.74 & 2.23 & 2.27 & 7.24 & $\begin{array}{l}\text { Competency } \\
\text { Upgrade Not } \\
\text { Needed }\end{array}$ \\
\hline Salting & 2.05 & 1.34 & 2.11 & 5.50 & $\begin{array}{l}\text { Competency } \\
\text { Upgrade Not } \\
\text { Needed }\end{array}$ \\
\hline Freezing & 1.77 & 1.24 & 1.57 & 4.58 & $\begin{array}{l}\text { Competency } \\
\text { Upgrade Not } \\
\text { Needed }\end{array}$ \\
\hline
\end{tabular}


S. Afr. J. Agric. Ext.

Vol. 47 No. 4, 2019: 86 - 95

http://dx.doi.org/10.17159/2413-3221/2019/v47n4a528
Olorunfemi, Olorunfemi, Adebayo, Letsoalo \& Modirwa

(License: CC BY 4.0)

\begin{tabular}{|c|c|c|c|c|c|}
\hline $\begin{array}{c}\text { Use of improved } \\
\text { smoking facilities for } \\
\text { fish processing }\end{array}$ & 3.57 & 2.63 & 3.74 & 9.94 & $\begin{array}{c}\text { Competency } \\
\text { Upgrade } \\
\text { Needed }\end{array}$ \\
\hline $\begin{array}{c}\text { Packaging and } \\
\text { labelling techniques }\end{array}$ & 3.22 & 2.54 & 2.92 & 8.68 & $\begin{array}{c}\text { Competency } \\
\text { Upgrade } \\
\text { Needed }\end{array}$ \\
\hline $\begin{array}{c}\text { Knowledge of } \\
\text { appropriate product } \\
\text { standardization for } \\
\text { domestic \& export } \\
\text { markets }\end{array}$ & 4.17 & 2.59 & 3.18 & 9.94 & $\begin{array}{c}\text { Competency } \\
\text { Upgrade } \\
\text { Needed }\end{array}$ \\
\hline $\begin{array}{c}\text { Knowledge on fish } \\
\text { disease diagnosis, } \\
\text { prevention and control }\end{array}$ & 2.28 & 2.02 & 2.00 & 6.84 & $\begin{array}{c}\text { Competency } \\
\text { Upgrade Not } \\
\text { Needed }\end{array}$ \\
\hline $\begin{array}{c}\text { Appropriate marketing } \\
\text { channels and } \\
\text { techniques }\end{array}$ & 4.20 & 2.52 & 2.20 & 8.92 & $\begin{array}{c}\text { Competency } \\
\text { Upgrade } \\
\text { Needed }\end{array}$ \\
\hline
\end{tabular}

\subsection{Constraints to the acquisition of needed competencies on value added fish production}

Table 3 indicates the constraints the extension agents encounter acquiring the needed competencies on value added fishery production. Using mean scores (MS) to rank the constraint items according to their order of severity as indicated by the respondents, "Lack of equipment and tools" (MS = 4.73), "Lack of technical know-how" $(\mathrm{MS}=4.40)$, "Inadequate and unstable funding" (MS= 4.21), "Unstable government policies" (MS=4.10), "Inadequate training opportunities" (MS = 3.97), "Poor motivation of extension agents" (MS = 3.88), and "Lack of adequate training resources" (MS = 3.81) were found to be very severe constraints. This finding is also in consonant with Adisa (2012) who reported that inadequate and unstable funding, lack of equipment, and inadequate training opportunities were major constraints limiting the acquisition of needed competency in fish farming by extension agents. The table further shows that the other listed constraint items with mean scores below 3.5 were of lesser severity to the extension agents in the study area.

Table 3: Respondents' constraints to the acquisition of needed competencies on value added fish production $(\mathbf{n}=120)$

\begin{tabular}{|l|l|l|l|l|l|l|l|}
\hline Constraints & $\begin{array}{c}\text { Very } \\
\text { severe }\end{array}$ & Severe & $\begin{array}{c}\text { Somewhat } \\
\text { severe }\end{array}$ & $\begin{array}{c}\text { A little } \\
\text { severe }\end{array}$ & $\begin{array}{c}\text { Not } \\
\text { severe }\end{array}$ & MS & Rank \\
\hline $\begin{array}{l}\text { Inadequate training } \\
\text { opportunities }\end{array}$ & $21(25)$ & $65.5(78)$ & $4.2(5)$ & $5.0(6)$ & $3.4(4)$ & 3.97 & $5^{\text {th }}$ \\
\hline $\begin{array}{l}\text { Poor linkages } \\
\text { between research } \\
\text { organisation and } \\
\text { extension }\end{array}$ & $5(6)$ & $53.8(64)$ & $26.1(31)$ & $10.9(13)$ & $3.4(4)$ & 3.47 & $9^{\text {th }}$ \\
\hline $\begin{array}{l}\text { Inadequate and } \\
\text { unstable funding }\end{array}$ & $40.3(48)$ & $45.4(54)$ & $1.7(2)$ & $4.2(5)$ & $3.4(4)$ & 4.21 & $3^{\text {rd }}$ \\
\hline $\begin{array}{l}\text { Insufficient time to } \\
\text { spare for knowledge } \\
\text { acquisition }\end{array}$ & $0.8(1)$ & $16.8(20)$ & $46.2(55)$ & $22.7(27)$ & $10.9(13)$ & 2.73 & $11^{\text {th }}$ \\
\hline
\end{tabular}




\begin{tabular}{|l|l|l|l|l|l|l|l|}
\hline $\begin{array}{l}\text { Poor motivation of } \\
\text { extension agents }\end{array}$ & $19.3(23)$ & $58.8(70)$ & $14.3(17)$ & $0.8(1)$ & $5.09(6)$ & 3.88 & $6^{\text {th }}$ \\
\hline $\begin{array}{l}\text { Unstable } \\
\text { government policies }\end{array}$ & $42.3(50)$ & $35.3(42)$ & $15.1(18)$ & $3.4(4)$ & $3.4(4)$ & 4.10 & $4^{\text {th }}$ \\
\hline Poor mentoring & $6.7(8)$ & $45.4(54)$ & $36.1(43)$ & $6.7(8)$ & $2.5(3)$ & 3.48 & $8^{\text {th }}$ \\
\hline $\begin{array}{l}\text { Lack of adequate } \\
\text { training resources }\end{array}$ & $11.8(14)$ & $63.9(76)$ & $10.9(13)$ & $4.2(5)$ & $3.4(4)$ & 3.81 & $7^{\text {th }}$ \\
\hline $\begin{array}{l}\text { Lack of equipment } \\
\text { and tools }\end{array}$ & $36.1(43)$ & $44.5(53)$ & $10.1(12)$ & $2.5(3)$ & $5.9(7)$ & 4.73 & $1^{\text {st }}$ \\
\hline $\begin{array}{l}\text { Too busy work } \\
\text { schedules }\end{array}$ & $2.5(3)$ & $21.8(26)$ & $24.4(29)$ & $31.1(37)$ & $19.3(23)$ & 2.57 & $12^{\text {th }}$ \\
\hline $\begin{array}{l}\text { Lack of subject } \\
\text { matter specialist }\end{array}$ & $9.2(11)$ & $24.4(29)$ & $49.6(59)$ & $12.6(15)$ & $4.2(5)$ & 3.21 & $10^{\text {th }}$ \\
\hline $\begin{array}{l}\text { Lack of technical } \\
\text { know-how }\end{array}$ & $47.9(57)$ & $45.4(54)$ & $5.9(7)$ & $0(0.0)$ & $0.8(1)$ & 4.40 & $2^{\text {nd }}$ \\
\hline
\end{tabular}

Note: The values in parenthesis represent the frequency (f) while the value outside represent the percentage $(\%)$.

\subsection{Relationship between the respondents' selected socio-economic characteristics and their competency needs on value added fish production techniques}

Table 4 revealed that there is a significant relationship between the extension agents' areas of competency needs on value added fish production and their age $\left(X^{2}=6.454\right)$, gender $\left(X^{2}=\right.$ 4.624), level of educational $\left(X^{2}=9.725\right)$, and years of experience $\left(X^{2}=12.586\right)$, thus the null hypothesis was rejected. Table 4 further reveals that there is no significant relationship between respondents' areas of competency needs on value added fish production and their marital status and household size, thus the null hypothesis was accepted. The implication of this result is that extension agents' competency needs on value added fish production are most likely to be influenced by their age, gender, level of education, and years of experience, while respondents' marital status and household size may not have any significant influence on their competency needs on value added fish production.

Table 4: The relationship between selected socio-economic characteristics of respondents and their areas of competency needs on value added fish production

\begin{tabular}{|l|l|l|l|l|}
\hline Variables & df & $\mathbf{X}^{\mathbf{2}}$ & Significance & Decision \\
\hline Age & 3 & 6.454 & 0.024 & Reject $\mathrm{H}_{\mathrm{o}}$ \\
\hline Gender & 1 & 4.624 & 0.001 & Reject $\mathrm{H}_{\mathrm{o}}$ \\
\hline Marital status & 1 & 2.827 & 0.535 & Accept $\mathrm{H}_{\mathrm{o}}$ \\
\hline Household size & 2 & 2.149 & 0.873 & Accept $\mathrm{H}_{\mathrm{o}}$ \\
\hline Level of education & 5 & 9.725 & 0.002 & Reject $\mathrm{H}_{\mathrm{o}}$ \\
\hline Years of experience & 2 & 12.586 & 0.037 & Reject $\mathrm{H}_{\mathrm{o}}$ \\
\hline
\end{tabular}

Significant level $=0.05$

\section{CONCLUSION AND RECOMMENDATIONS}

Based on the findings of the study, the extension agents highly needed competency upgrade and training in 10 major areas of value added fish production as indicated by the respondents. 
S. Afr. J. Agric. Ext.

Vol. 47 No. 4, 2019: 86 - 95

http://dx.doi.org/10.17159/2413-3221/2019/v47n4a528
Olorunfemi, Olorunfemi, Adebayo, Letsoalo \& Modirwa

(License: CC BY 4.0)

The severe constraints encountered in the acquisition of needed competency accounted for the low competency profile of the extension agents in value added fish production. The study therefore recommends that the Agricultural Development Programme in Kwara State should package a robust capacity building and training programme for extension agents in the major areas of competency deficiencies as previously indicated. This training programme will enhance the knowledge and skills of the extension agents for onward transmission to the farmers. Furthermore, government should look into addressing the constraints highlighted by the extension agents so as to properly equip them in training farmers to tap into all the available potentials that exist in the fishery sector.

\section{REFERENCES}

ADEFALU, L.L., ADERINOYE-ABDULWAHAB, S.A., BELLO, O.G., OLORUNFEMI, O.D. \& OBA, S.A., 2013. Information needs of fish farmers in Ilorin Metropolis, Kwara State, Nigeria. NGA. J. Agric. Food Environ., 9(2):1-5.

ADISA, R.S., 2012. A study of fish farming competency among agricultural extension agents in North Central Nigeria. Niugini Agrisaiens, 4(1):26-33.

BÈNÈ, C., BARANGE, M., SUBASINGHE, R., PINSTRUP-ANDERSEN, P., MERINO, G., HEMRE, G.I. \& WILLIAMS, M., 2015. Feeding 9 billion by 2050 - putting fish back on the menu. Food Secur., 7(2):261-274.

BROWN, T.J., AGBUlU, O.N., AMONJENU, A., 2017. Approaches for enhancing sustainable fish production among farmers in Bayelsa State, Nigeria. J. Fisheries Livest. Prod., 5(3):1-6.

FOOD AND AGRICULTURAL ORGANISATION (FAO), 2014. The state of world fisheries and aquaculture. Available from: http://www.fao.org/3/a-i3720e.pdf

FOOD AND AGRICULTURAL ORGANISATION (FAO), 2016. Fisheries in the drylands of Sub-Saharan Africa. Available from: http://www.fao.org/3/a-i5616e.pdf

FOOD AND AGRICULTURAL ORGANISATION (FAO), 2018. The state of world fisheries and aquaculture. Available from: http://www.fao.org/3/I9540EN/i9540en.pdf

HALEEM, K.B., 2018. Training needs of extension agents in AL Diwaniyah Province, Iraq. $J$. Agric. Ext., 22(2):125-135.

IDRISA, Y.L. \& OGUNBAMERU, B.O., 2008. Farmers' assessment of the unified agricultural extension service in Borno State, Nigeria. J. Agric. Ext., 11(1):106-114.

IFEJIKA, P.I., UZOKWE, U.N. \& OLADOSU, O.I., 2013. Training needs of table fish farmers operating in Niger State, Nigeria. World Rural Observ., 5(4):108-113.

KWARA STATE AGRICULTURAL DEVELOPMENT PROJECT (KWADP), 2015. Agronomic Survey Report. Kwara, Nigeria.

MELTON, B. \& BAHLIS, J.J., 2011. ADVISOR enterprise Difficulty-Importance-Frequency (DIF) model fact sheet. Available from: www.bnhexpertsoft.com

MOORE, D.A., TRUSCOTT, M.L., KIRK, J. \& KLINGBORG, D.J. 2007. Does adding an extra educational intervention add value? The dairy beef train-the-trainers program. $J$. Ext., 45(3). 
S. Afr. J. Agric. Ext.

Vol. 47 No. 4, 2019: 86 - 95

http://dx.doi.org/10.17159/2413-3221/2019/v47n4a528
Olorunfemi, Olorunfemi, Adebayo, Letsoalo \& Modirwa

(License: CC BY 4.0)

MORRISEY, M., 2011. Development of value-added products in aquaculture. Available from: https://www.uanl.mx/utilerias/nutricion_acuicola/XI/archivos/2-morriseymichael.pdf

NATIONAL BUREAU OF STATISTICS (NBS), 2017. Nigerian Gross Domestic Product Report No. Q3/2017. Abuja, Nigeria.

OGUNLADE, I., OLADELE, O.I. \& BABATUNDE, A.O., 2009. Farmers' attitude to beneficiary funding of extension services in Kwara State, Nigeria. J. Hum. Ecol., 26(3):215-220.

OLAOYE, O.J. \& OLORUNTOBA, A., 2011. Determinants of aquaculture technologies adoption among fish farmers in Obafemi-Owode local government area of Ogun State. Nigeria. J. Hum. Soc. Sci. Crtv. Arts, 5(1):37-48.

OLORUNFEMI, O.D., OLORUNFEMI, T.O, OLADELE, O.I. \& ADEKUNLE, O.A., 2018. Determinants of extension agents' competency on value added fish production: Evidence from Nigeria. J. Dev. Areas, 52(3):15-25.

OLORUNFEMI, O.D., ADEKUNLE, O.A., OLADIPO, F.O., OLADELE, T.O. \& OLADELE, O.I., 2017. Training needs of fish farmers on value addition initiatives in Kwara State, Nigeria. Sarhad J. Agric., 33(1):14-21.

SAIKIA, P., KRISHNAN, M., ANANTHAN, P.S., SHEELA, I. \& HAZARIKA, D., 2013. Delivery competence and penetration of extension services among fish farmers of Assam. Ind. Jn. of Agri. Econ., 68(3):402-411.

WALIA, P., 2007. Value addition in agricultural products: A case study of mango processing. Available from: http//www.commongroundgroup.com/conference.html

WENTLING, T.L., 1993. Planning for effective training: A guide to curriculum development. Rome: Food and Agricultural Organisation. 
